\title{
Staging more important than grading? Evaluation of malignancy grading, depth of invasion, and resection margins in oral squamous cell carcinoma
}

\author{
Michael Wunschel $^{1}$ (D) $\cdot$ Miriam Neumeier $^{1} \cdot$ Kirsten Utpatel $^{2} \cdot$ Torsten E. Reichert $^{1} \cdot$ Tobias Ettl $^{1} \cdot$ Gerrit Spanier $^{1}$
}

Received: 3 April 2020 / Accepted: 18 June 2020 / Published online: 29 June 2020

(C) The Author(s) 2020

\begin{abstract}
Objectives The present study evaluated the predictive value of staging and grading parameters concerning the presence of lymphnode metastases, overall survival (OS), and relapse-free survival (RFS) of patients with oral squamous cell carcinoma (OSCC). Materials and methods HE-stains of 135 surgically treated (R0) primary OSCCs were analyzed using a both microscopic and software-based approach. Depth of invasion (DOI) and resection margins (RM) were measured, and each case was graded according to the malignancy grading system as described by Anneroth et al. and Bryne et al. on two different sites of the tumor (surface and invasion front; TS and IF).

Results Parameters that could be identified as significant predictors of OS and RFS were UICC cancer stage ( $p=0.009$ and $p=$ 0.012 ); pT-stage as defined in the 7th edition ( $p=0.029$ and 0.015$)$ and, after restaging using DOI, 8 th edition $(p=0.023$ and $p=$ $0.005)$ of the TNM classification of malignant tumors; the presence of lymphonodular metastases (LM) $(p=0.004$ and $p=$ $0.011)$; degree of keratinization ( $p=0.029$ and $p=0.042)$; and pattern of growth $(p=0.029$ and $p=0.024)$ at the TS after applying a binary scale for both parameters. Also, when directly comparing the most extreme subgroups (scores 1 and 4 ) of lymphoplasmacytic infiltration at the IF, there was a significant difference in OS $(p=0.046)$ and RFS $(p=0.005)$. Invasion of blood vessels $(p=0.013)$ and perineural invasion $(p=0.023)$ were significantly associated with a lower OS. Age lower than 60 years (univariate $p=0.029$, multivariate $p=0.031)$, infiltration of lymphatic vessels $(p=0.003)$, infiltration of nerves $(p=$ $0.010)$, pT-stage (8th edition) ( $p=0.014)$, degree of keratinization at the IF $(p=0.033)$, and nuclear polymorphism at the IF $(p=$ 0.043 ) after conversion to a binary scale were found to be significant prognostic parameters regarding the presence of LM. DOI evolved as a significant predictor for $\operatorname{OS}(p=0.006)$, RFS $(p=0.003)$, and LM $(p=0.032)$ in metric and grouped analysis.

Conclusions The current evaluation revealed depth of invasion as strongest histologic predictor of metastatic tumor growth, overall survival, and relapse-free survival in OSCC, confirming the current adaption of the T-classification. Other distinct histologic grading parameters investigated during this study can give valuable indications of a tumor's potential aggressiveness, but the exact site, mode, and procedure need further exploration.

Clinical relevance Integrating measurement of DOI also into the pretherapeutic staging process could aid in treatment planning.
\end{abstract}

Keywords Oral squamous cell carcinoma $\cdot$ Depth of invasion $\cdot$ Resection margin $\cdot$ Malignancy grading

Tobias Ettl and Gerrit Spanier contributed equally to this work.

Michael Wunschel

michael.wunschel@ukr.de

1 Department of Cranio-Maxillofacial Surgery, University Hospital Regensburg, Regensburg, Germany

2 Institute of Pathology, University Regensburg, Regensburg, Germany

\section{Objectives}

More than 500.000 new cases of head and neck squamous cell carcinoma (HNSCC) are diagnosed every year with a constant increase of oral squamous cell carcinoma (OSCC) and a decline in laryngeal and hypopharyngeal cancer over the past decade [1]. The annual incidence of oral cancer is estimated to be more than 300.000 and the annual mortality 145.000 deaths worldwide. OSCC constitutes $90 \%$ of these cases [2]. Despite significant improvement in diagnostics 
and treatment since the 1970s [3], overall survival remains not satisfactory.

Current treatment options include surgical resection, radiation therapy, chemotherapy, and immunotherapy [4] based on national and international guidelines [5, 6]. Primary tumor resection with immediate reconstruction is usually performed in cases where localized disease is approachable with curative intention [6]. Adjuvant radiotherapy or systemic therapy with concurrent radiotherapy is used in cases with late-stage cancer or with adverse features like positive lymph nodes, extranodal extension, and involved or positive resection margins [7]. Patients with non-resectable tumors or medical conditions impeding surgery can be curatively treated with systemic therapy or irradiation or combination of both [7]. First-line therapy of very advanced, recurrent, or metastatic HNSCC currently consists of a combination of a platinum-based agent, fluorouracil and cetuximab [8]. Recently, new therapeutic options, which are directed at countering a tumor's immune-evasion capabilities, for example, its expression of programmed death ligand 1 (PD-L1), are emerging [9]. Until now, monoclonal anti-PD1 antibodies like nivolumab or pembrolizumab are recommended as second-line therapy in cases of tumor progression during or after first-line treatment [7], but more and more reports suggest superiority of these immune-based approaches to the established platinum-based treatment protocols $[10,11]$.

Among other criteria the choice of treatment vastly depends on patient's tumor stage and grade. While histopathological grading according to the WHO classification of head and neck tumors often lacks significant prognostic value [12-14], clinical staging according to AJCC or UICC TNM classifications constitutes a major prognostic factor $[12,15,16]$.

Several attempts have been made to improve the predictive accuracy introducing additional histologic parameters like tumor thickness, growth pattern, invasive front malignancy grading, tumor budding, or depth of invasion (DOI) [12, 17-20]. The latter has been included into the current (UICC, AJCC, eighth edition) TNM classification of malignant tumors of the oral cavity $[15,16]$.

The aim of the present study was to evaluate the predictive value of additional histologic parameters concerning the presence of lymph-node metastases (LM), overall survival (OS), and relapse-free survival (RFS) of patients with OSCC.

\section{Materials and methods}

\section{Patients}

The study comprises 135 adult patients diagnosed and treated for newly diagnosed OSCC at the Department of CranioMaxillofacial Surgery, University Hospital Regensburg between January 2013 and December 2016. Patients with previous neck dissection or primary systemic or radiotherapy of head and neck squamous cell carcinoma were excluded. All participants underwent surgical resection of the primary lesion to negative margins as well as neck dissection based on the clinical and radiologic findings. Only cases with definite histologically clear margins (R0) after surgery were included. Patients were staged according to the UICC guidelines of the 7th edition [21]. Patient data (age, sex, history of smoking and alcohol, tumor site, TNM stage, UICC stage, surgical therapy) were retrieved from the medical records for retrospective analysis.

Adjuvant treatment (radiotherapy and/or systemic therapy) was based on the recommendation of the multidisciplinary tumor board. Disease relapse was defined as local disease recurrence or distant metastasis by radiologic evidence with clinical correlation or histologic confirmation by biopsy. Follow-up data concerning recurrence-free survival (RFS) and overall survival (OS) were obtained from medical records, death certificates, registration offices, and the Clinical Cancer Registry of the Tumor Centre-Institute for Quality Management and Health Services Research, University of Regensburg, Germany.

\section{Specimen and histological evaluation}

Standard formalin-fixed, paraffin-embedded tissue samples of all patients were retrieved from the archive of the Institute of Pathology, University of Regensburg, Germany. For HEstaining, $4 \mu \mathrm{m}$ sections were deparaffinized with xylene and ethanol and stained with HE according to standard protocol. For analysis an Axiostar plus microscope (Carl Zeiss, Göttingen, Germany) with a $\mathrm{Cl} 10 \times$ ocular (Carl Zeiss, Göttingen, Germany) and CP-Achromat microscope $5 \times$, $10 \times$, and $40 \times$ objectives (Carl Zeiss, Göttingen, Germany) was used. All available HE-slides with tissue of the primary tumor were analyzed, and the one most suitable slide for each site investigated (tumor surface (TS) and invasion front (IF)) was selected. Selection criteria included quantity of visible tumor cells, quality of stain, and lack of preparation artifacts or other structural damages to the tissue. Optimal slides were scanned in a Pannoramic 250 FLASH III (Sysmex, Norderstedt, Germany) scanner, and accordant JPEG-format files $(2520 \times 1481$ pixels $\times 24$ Bit $)$ were generated. Digital images were evaluated by using Caseviewer Software (Sysmex, Norderstedt, Germany).

Depth of invasion (DOI) and resection margins (RM) were measured with micrometer precision. DOI was defined as the maximum distance from the basal membrane to the tumor's deepest margin [16] (see Fig. 1). DOI was then used to restage tumors according to the 8th edition of the TNM classification of malignant tumors [15] creating a "new pTstage"-variable. RM was defined as the minimum distance of a tumor margin to the border of a tissue specimen. Oriented 


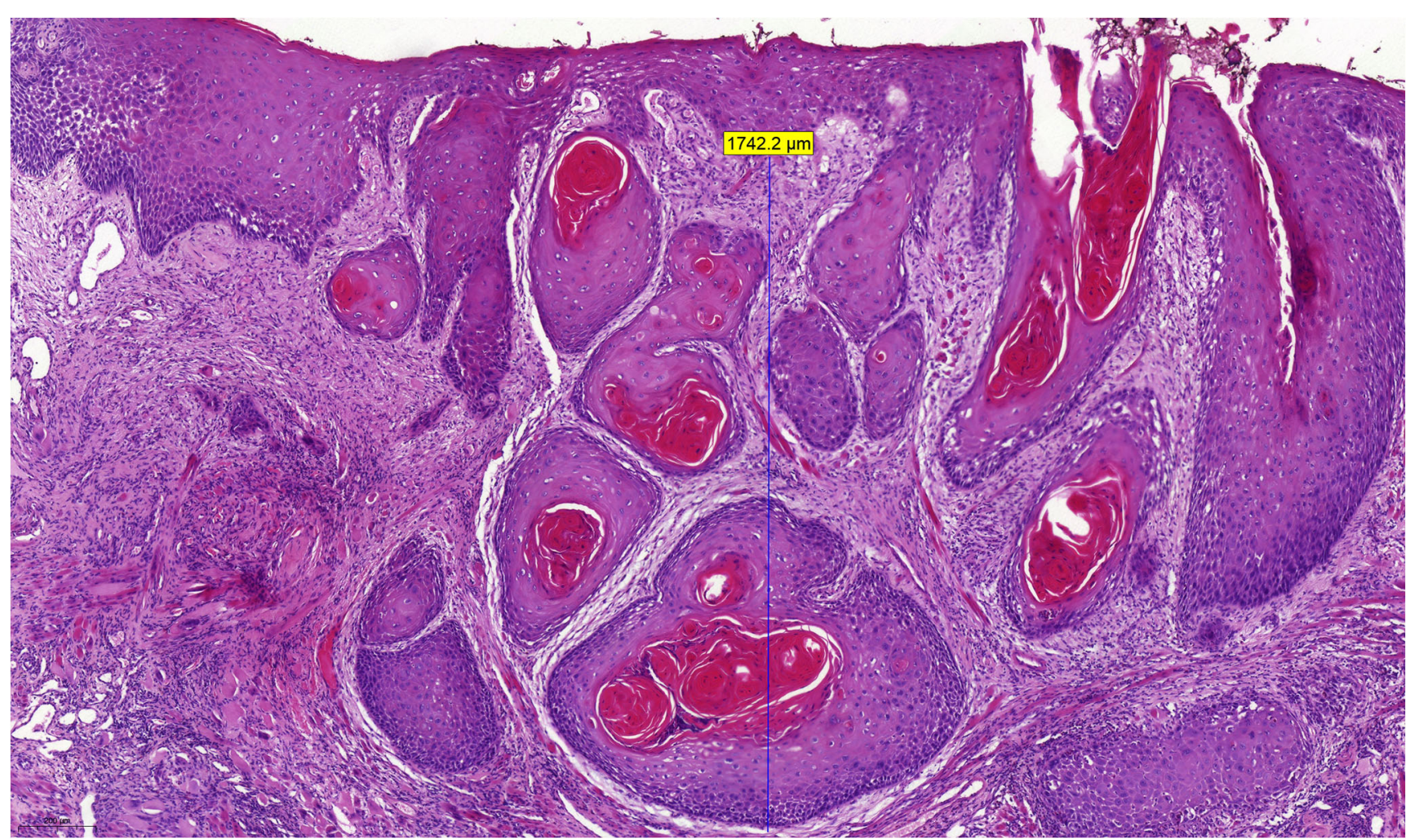

Fig. 1 Histopathological slide of an oral squamous cell carcinoma showing measurement of DOI (magnification $\times 7.0$ )

tumor-free safety margin excisions were added to the corresponding value. Each case was then graded according to the malignancy grading system as described by Anneroth et al. [20] and Bryne et al. [18, 22]. Each parameter including degree of keratinization, nuclear polymorphism, number of mitoses per high power field (HPF), pattern of growth/invasion, and lymphoplasmacytic invasion was given a grade/ score of 1-4 [23] (Table 1). Further analysis was carried out by dichotomizing the results of each parameter by combining scores/grades 1 and 2 into a low-risk group 1 and scores/grades 3 and 4 into a high-risk group 2. In contrast to the concept of "invasive cell grading (ICG)" [23], we investigated tumor surface (TS) - as obtained from biopsies - and invasion front (IF) separately, if sufficient material for distinct observation was available. Cells at the tumor surface were also grouped according to the criteria

Table 1 Histological malignancy grading system according to Anneroth (1987) [20] and Bryne (1992) [23]

\begin{tabular}{|c|c|c|c|c|}
\hline \multirow[t]{2}{*}{ Morphological feature } & \multicolumn{4}{|l|}{ Score } \\
\hline & 1 & 2 & 3 & 4 \\
\hline Degree of keratinization & $\begin{array}{l}\text { Highly keratinized } \\
\qquad(>50 \% \text { of the cells })\end{array}$ & $\begin{array}{l}\text { Moderately keratinized } \\
(20-50 \% \text { of the cells })\end{array}$ & $\begin{array}{l}\text { Minimal keratinization } \\
\quad(5-20 \% \text { of the cells })\end{array}$ & $\begin{array}{l}\text { No keratinization } \\
\quad(0-5 \% \text {, of the cells })\end{array}$ \\
\hline Nuclear polymorphism & $\begin{array}{l}\text { Little nuclear polymorphism } \\
\text { (> 75\% mature cells) }\end{array}$ & $\begin{array}{l}\text { Moderately abundant } \\
\text { nuclear polymorphism } \\
\text { (50-75\% mature cells) }\end{array}$ & $\begin{array}{l}\text { Abundant nuclear polymorphism } \\
\quad(25-50 \% \text { mature cells })\end{array}$ & $\begin{array}{l}\text { Extreme nuclear } \\
\text { polymorphism } \\
\quad(0-25 \% \text { mature cells })\end{array}$ \\
\hline $\begin{array}{l}\text { Number of mitoses } \\
\text { (high power field) }\end{array}$ & $0-1$ & $2-3$ & $4-5$ & $>5$ \\
\hline Pattern of growth/invasion & $\begin{array}{l}\text { Pushing, well-delineated infil- } \\
\text { trating borders }\end{array}$ & $\begin{array}{l}\text { Infiltrating, solidcords, } \\
\text { bands, and/or strands }\end{array}$ & $\begin{array}{l}\text { Small groups orcords of } \\
\quad \text { infiltrating cells }(n>15)\end{array}$ & $\begin{array}{l}\text { Marked and widespread } \\
\text { cellular dissociation } \\
\text { in small groups } \\
\text { and/or in single cells } \\
(n<15)\end{array}$ \\
\hline $\begin{array}{l}\text { Lymphoplasmacytic } \\
\text { infiltration }\end{array}$ & Marked & Moderate & Slight & None \\
\hline
\end{tabular}


previously described as "pattern of invasion" [20], referring to this investigation as "pattern of growth." In cases, where distinct analysis was not possible, the data were attributed to the invasion front subgroup. See Fig. 2 with examples of the four categories of invasion patterns. Shown are different grades of invasion patterns representing differences in cellto-cell cohesiveness from intact, well-delineated margins in differentiated tumors (grade 1) to single invasive cells in undifferentiated tumors (grade 4). The number of mitoses was counted reviewing ten HPF and recorded as exact number and coded as a score as shown in Table 1. All scores were then summoned up into one malignancy score for tumor surface and invasion front respectively [22].

Histologic investigation and grading were independently performed by three investigators (MW, MN, and KU) without knowing the clinical follow-up of the patients in a blinded approach. In case of divergent assessment, consent was obtained after joint re-evaluation.

\section{Statistical analysis}

Metric variables were analyzed for differences in their means, using Student's $t$ test in case of log-normal distribution, otherwise using Mann-Whitney $U$ test. Independence or
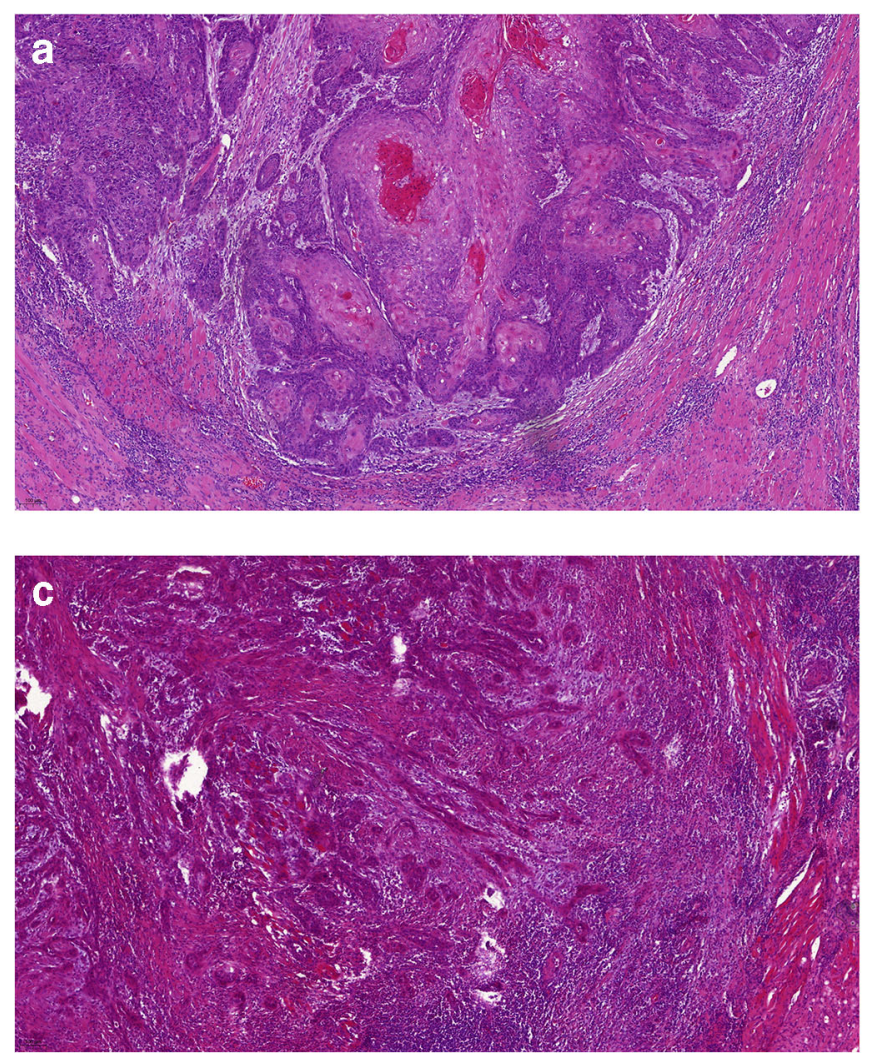

Fig. 2 Histopathological slides of oral squamous cell carcinoma showing examples for different patterns of invasion (magnification $\times 8.0$ ): $\mathbf{A}$ grade 1, pushing, well-delineated infiltrating borders; B grade 2, infiltrating,

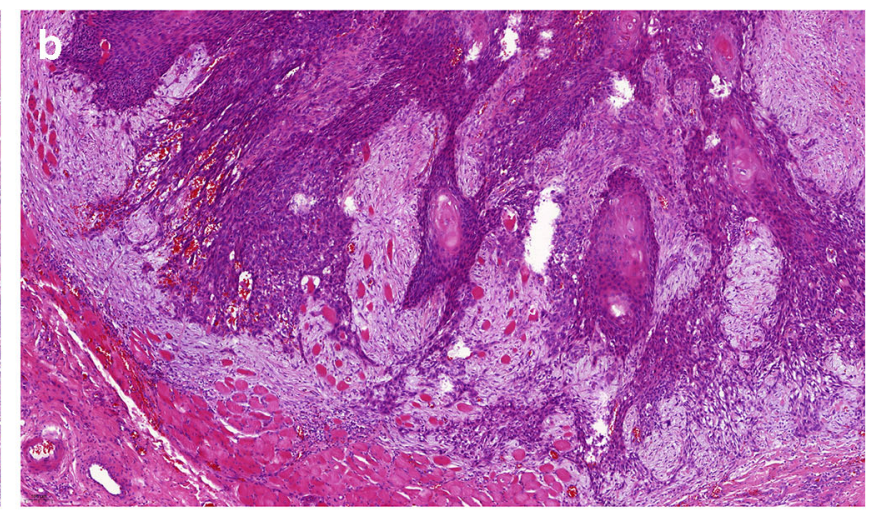

correlation of categorical variables was analyzed using Pearson's chi-squared test and reporting the Phi-coefficient. Multivariate correlation analysis was performed using a binary logistic regression model. OS and RFS time were calculated from date of resection to date of death, date of recurrence, or date last alive until cut-off date June 30, 2019. Survival analyses were performed using univariate Kaplan-Meier and multivariate Cox regression method. Differences in outcome estimates were tested using the log-rank test. Results were reported with hazard ratios (HRs) and 95\% confidence interval (CI). A $p<0.05$ was considered significant for all tests. All data were anonymized, and analyses were performed using IBM SPSS Statistics Version 25.0 (IBM Corp., Armonk, N.Y., USA).

\section{Results}

After applying the study's criteria, 135 patients, thereof 94 males and 41 females, were included. Mean age at the time of the operation was 62.69 years. The majority of patients reported a history of smoking or alcohol, or a combination of both and OSCC in this collective was most frequently

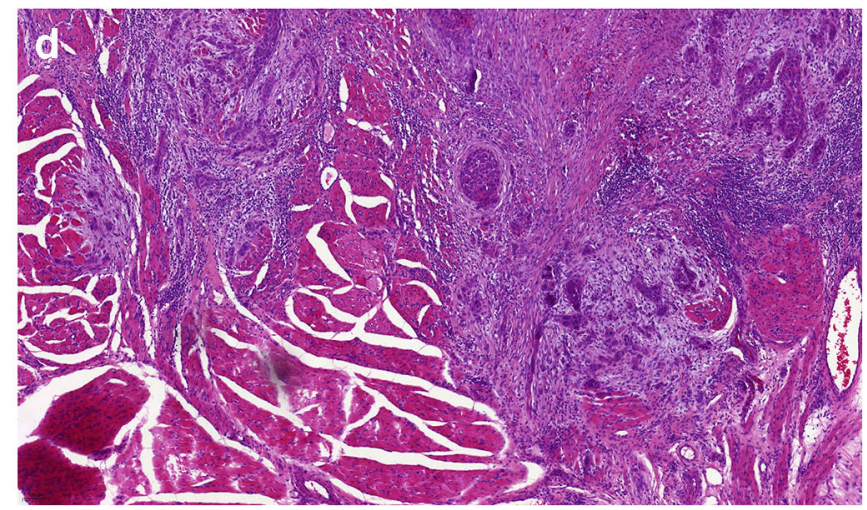

solid cords, bands, and/or strands; $\mathbf{C}$ grade 3, small groups or cords of infiltrating cells $(n>15)$; and $\mathbf{D}$ grade 4 , marked and widespread cellular dissociation in small groups and/or in single cells $(n<15)$ 
located in the tongue or floor of mouth. Additional patient and tumor data are shown in Tables 2 and 3.

\section{Univariate survival analysis of standard parameters}

Mean observation period was 1193.83 days. Estimated mean overall survival was $1618.83( \pm 70.28 ; 1481.08-1756.5895 \%$ CI) days, resulting in a 2-year survival rate (2YSR) of $76.3 \%$ $( \pm 3.7 \%)$ and a 5 -year survival rate $(5 \mathrm{YSR})$ of $60.4 \%$ ( \pm $4.9 \%)$. Estimated mean RFS was $1449.86( \pm 77.42$; 1298.11-1601.61 95\% CI) days. Mean time to relapse was 360 ( $\pm 283 ; 254-46595 \%$ CI; 39 min, 1376 max) days.

See Tables 2 and 3 for results of univariate survival analysis.

For statistical analysis, cancer stages IVa and IVc as defined in the 7th edition of UICC cancer manuals [21] were combined to one stage IV, because there was only one case with stage IVc. The same applied for G4 grade, which-in concordance with international standards [16] —was counted in the G3-subgroup.
Following standard staging parameters showed significant association with OS and RFS: UICC cancer stage, pathohistological pT-stage, as defined in the 7th edition of the TNM classification of malignant tumors [21] and the presence of lymphonodular metastases (LM). The number of infiltrated lymph nodes was a significant predictor of $\operatorname{OS}(\operatorname{Exp}(B)=1.201$, $p<0.001)$ and $\operatorname{RFS}(\operatorname{Exp}(B)=1.149, p<0.001)$.

Invasion of blood vessels and perineural invasion were associated with significantly worse overall survival. This association was not observed for RFS.

All other standard and staging parameters did not show statistical significance for OS or RFS.

\section{Univariate survival analysis of additional histological parameters}

\section{Depth of invasion and resection margin}

In Cox regression analysis, DOI was identified as a significant parameter of OS and RFS. A cut-off value separating low-risk

Table 2 Patient and tumor data

\begin{tabular}{|c|c|c|c|c|}
\hline Parameter & Variable & Value & $\begin{array}{l}\text { Test result } \\
\text { (overall survival) }\end{array}$ & $\begin{array}{l}\text { Test result } \\
\text { (relapse-free survival) }\end{array}$ \\
\hline \multicolumn{5}{|l|}{ Observation period (days) } \\
\hline & Mean (range) & $1193.83(17-2228)$ & & \\
\hline \multirow[t]{3}{*}{ Gender } & & & $\chi^{2}(1)=0.023, p=0.880$ & $\chi^{2}(1)=0.019, p=0.890$ \\
\hline & Male & $94(69.6 \%)$ & & \\
\hline & Female & $41(30.4 \%)$ & & \\
\hline \multirow[t]{2}{*}{ Age (years) } & & & $\operatorname{Exp}(B)=1.004, p=0.751$ & $\operatorname{Exp}(B)=1.008, p=0.480$ \\
\hline & Mean (range) & $62.69(27-90)$ & & \\
\hline \multirow[t]{3}{*}{ History of smoking } & & & $\chi^{2}(1)=1.273, p=0.259$ & $\chi^{2}(1)=0.675, p=0.411$ \\
\hline & Yes & $89(65.9 \%)$ & & \\
\hline & No & $46(34.1 \%)$ & & \\
\hline \multirow[t]{3}{*}{ History of alcohol } & & & $\chi^{2}(1)=0.337, p=0.562$ & $\chi^{2}(1)=0.932, p=0.334$ \\
\hline & Yes & $80(59.3 \%)$ & & \\
\hline & No & $55(40.7 \%)$ & & \\
\hline \multirow[t]{7}{*}{ Localization of tumor } & & & $\chi^{2}(5)=3.939, p=0.558$ & $\chi^{2}(5)=4.566, p=0.471$ \\
\hline & Buccal plane & $15(11.1 \%)$ & & \\
\hline & Maxilla & $6(4.4 \%)$ & & \\
\hline & Mandible & $20(14.8 \%)$ & & \\
\hline & Palate & $6(4.4 \%)$ & & \\
\hline & Tongue & $43(31.9 \%)$ & & \\
\hline & Floor of mouth & $45(33.3 \%)$ & & \\
\hline \multirow[t]{2}{*}{ Depth of invasion (mm) } & & & $\operatorname{Exp}(B)=1.067, p=0.015$ & $\operatorname{Exp}(B)=1.082, p=0.001$ \\
\hline & Mean (range) & $8.505(0.997-25.867)$ & & \\
\hline \multirow[t]{2}{*}{ Safety margin (mm) } & & & $\operatorname{Exp}(B)=0.924, p=0.117$ & $\operatorname{Exp}(B)=0.950, p=0.244$ \\
\hline & Mean (range) & $6.024(0.172-16.995)$ & & \\
\hline
\end{tabular}

Significant results are shown in italics 
Table 3 Univariate analysis of overall (OS) and recurrence-free (RFS) survival. Only statistically significant parameters are shown

\begin{tabular}{|c|c|c|c|c|c|c|c|c|}
\hline \multirow{2}{*}{ Parameter } & & \multirow{2}{*}{ Number } & \multirow{2}{*}{$\begin{array}{l}\text { OS } \\
\text { 2YSR (\%) }\end{array}$} & \multirow{2}{*}{ 5YSR (\%) } & \multirow{2}{*}{ Test result } & \multicolumn{2}{|l|}{ RFS } & \multirow{2}{*}{ Test result } \\
\hline & & & & & & 2YSR (\%) & 5YSR (\%) & \\
\hline \multirow[t]{5}{*}{ UICC } & & & & & $\begin{array}{c}\chi^{2}(3)=11.672 \\
p=0.009\end{array}$ & & & $\begin{array}{c}\chi^{2}(3)=10.979 \\
p=0.012\end{array}$ \\
\hline & I & $38(28.1 \%)$ & $97.4 \pm 2.6$ & $74.1 \pm 9.1$ & & $86.8 \pm 5.5$ & $65.7 \pm 9.7$ & \\
\hline & II & $20(14.8 \%)$ & $90.0 \pm 6.7$ & $63.0 \pm 16.0$ & & $85.0 \pm 8.0$ & $53.0 \pm 15.0$ & \\
\hline & III & $22(16.3 \%)$ & $59.1 \pm 10.5$ & $47.3 \pm 11.2$ & & $54.5 \pm 10.6$ & $48.5 \pm 11.0$ & \\
\hline & IV & $55(40.7 \%)$ & $63.6 \pm 6.5$ & $54.3 \pm 7.0$ & & $52.7 \pm 6.7$ & $44.5 \pm 6.8$ & \\
\hline \multirow[t]{5}{*}{ pT (7th Ed.) } & & & & & $\begin{array}{c}\chi^{2}(3)=9.011 \\
p=0.029\end{array}$ & & & $\begin{array}{c}\chi^{2}(3)=10.418 \\
p=0.015\end{array}$ \\
\hline & 1 & $51(37.8 \%)$ & $90.2 \pm 4.2$ & $67.9 \pm 7.9$ & & $78.4 \pm 5.8$ & $63.0 \pm 8.1$ & \\
\hline & 2 & $39(28.9 \%)$ & $76.9 \pm 6.7$ & $57.0 \pm 11.2$ & & $69.2 \pm 7.4$ & $45.4 \pm 11.1$ & \\
\hline & 3 & $13(9.6 \%)$ & $38.5 \pm 13.5$ & $38.5 \pm 13.5$ & & $30.8 \pm 12.8$ & $30.8 \pm 12.8$ & \\
\hline & $4 a$ & $32(23.7 \%)$ & $68.8 \pm 8.2$ & $57.8 \pm 9.0$ & & $62.5 \pm 8.6$ & $49.0 \pm 9.0$ & \\
\hline \multirow[t]{5}{*}{ pT (8th Ed.) } & & & & & $\begin{array}{c}\chi^{2}(3)=9.576 \\
p=0.023\end{array}$ & & & $\begin{array}{c}\chi^{2}(3)=12.997 \\
p=0.005\end{array}$ \\
\hline & 1 & $28(20.7 \%)$ & $92.9 \pm 4.9$ & $74.5 \pm 9.4$ & & $85.7 \pm 6.6$ & $67.5 \pm 9.9$ & \\
\hline & 2 & $34(25.2 \%)$ & $85.3 \pm 6.1$ & $66.5 \pm 10.5$ & & $73.5 \pm 7.6$ & $59.9 \pm 11.5$ & \\
\hline & 3 & $32(23.7 \%)$ & $56.3 \pm 8.8$ & $42.4 \pm 9.7$ & & $43.8 \pm 8.8$ & $31.2 \pm 8.8$ & \\
\hline & $4 a$ & $32(23.7 \%)$ & $68.8 \pm 8.2$ & $57.8 \pm 9.0$ & & $62.5 \pm 8.6$ & $49.0 \pm 9.0$ & \\
\hline \multirow[t]{3}{*}{ V } & & & & & $\begin{array}{c}\chi^{2}(1)=6.128 \\
p=0.013\end{array}$ & & & $\begin{array}{c}\chi^{2}(1)=2.439 \\
p=0.118\end{array}$ \\
\hline & 0 & $131(97.0 \%)$ & $77.9 \pm 3.6$ & $61.5 \pm 4.9$ & & $68.7 \pm 4.1$ & $53.6 \pm 4.9$ & \\
\hline & 1 & $4(3.0 \%)$ & $25.0 \pm 21.7$ & $25.0 \pm 21.7$ & & $25.0 \pm 21.7$ & $25.0 \pm 21.7$ & \\
\hline \multirow[t]{3}{*}{ Pn } & & & & & $\begin{array}{c}\chi^{2}(1)=5.147 \\
p=0.023\end{array}$ & & & $\begin{array}{c}\chi^{2}(1)=5.147 \\
\quad p=0.120\end{array}$ \\
\hline & 0 & $120(88.9 \%)$ & $80.0 \pm 3.7$ & $63.1 \pm 5.2$ & & $70.0 \pm 4.2$ & $54.5 \pm 5.2$ & \\
\hline & 1 & $15(11.1 \%)$ & $46.7 \pm 12.9$ & $40.0 \pm 12.6$ & & $46.7 \pm 12.9$ & $40.0 \pm 12.6$ & \\
\hline \multirow[t]{3}{*}{$\begin{array}{l}\text { Lymphonodular } \\
\text { metastasis }\end{array}$} & & & & & $\begin{array}{c}\chi^{2}(1)=8.472 \\
p=0.004\end{array}$ & & & $\begin{array}{c}\chi^{2}(1)=6.434 \\
p=0.011\end{array}$ \\
\hline & neg. & $85(63.0 \%)$ & $85.9 \pm 3.8$ & $66.7 \pm 6.3$ & & $77.6 \pm 4.5$ & $57.1 \pm 6.4$ & \\
\hline & pos. & $49(36.3 \%)$ & $61.2 \pm 7.0$ & $50.4 \pm 7.6$ & & $51.0 \pm 7.1$ & $46.1 \pm 7.3$ & \\
\hline \multirow[t]{4}{*}{ Depth of invasion } & & & & & $\begin{array}{c}\chi^{2}(2)=7.701 \\
p=0.021\end{array}$ & & & $\begin{array}{c}\chi^{2}(2)=10.614 \\
p=0.005\end{array}$ \\
\hline & $<5 \mathrm{~mm}$ & $37(29.6 \%)$ & $94.6 \pm 3.7 \%$ & $75.5 \pm 7.8 \%$ & & $89.2 \pm 5.1 \%$ & $70.4 \pm 8.1 \%$ & \\
\hline & $5 \leq \mathrm{DOI}<10 \mathrm{~mm}$ & $43(34.4 \%)$ & $76.7 \pm 6.4 \%$ & $62.0 \pm 9.0 \%$ & & $65.1 \pm 7.3 \%$ & $52.9 \pm 9.2 \%$ & \\
\hline & $\geq 10 \mathrm{~mm}$ & $45(36.0 \%)$ & $57.8 \pm 7.4 \%$ & $48.8 \pm 7.8 \%$ & & $46.7 \pm 7.4 \%$ & $38.5 \pm 7.5 \%$ & \\
\hline \multicolumn{9}{|l|}{ Tumor surface } \\
\hline \multirow[t]{3}{*}{$\begin{array}{l}\text { Degree of } \\
\text { keratinization } \\
\text { (dichotomized) }\end{array}$} & & & & & $\begin{array}{c}\chi^{2}(1)=4.752 \\
p=0.029\end{array}$ & & & $\begin{array}{c}\chi^{2}(1)=4.144 \\
p=0.042\end{array}$ \\
\hline & 1 & $89(85.6 \%)$ & $78.7 \pm 4.3$ & $65.7 \pm 5.8$ & & $68.5 \pm 4.9$ & $55.7 \pm 5.9$ & \\
\hline & 2 & $15(14.4 \%)$ & $53.3 \pm 12.9$ & $38.9 \pm 12.9$ & & $40.0 \pm 12.6$ & $33.3 \pm 12.2$ & \\
\hline \multirow[t]{3}{*}{$\begin{array}{l}\text { Pattern of growth } \\
\text { (dichotomized) }\end{array}$} & & & & & $\begin{array}{c}\chi^{2}(1)=4.753 \\
p=0.029\end{array}$ & & & $\begin{array}{c}\chi^{2}(1)=4.582 \\
p=0.032\end{array}$ \\
\hline & 1 & $37(35.6 \%)$ & $91.9 \pm 4.5$ & $74.9 \pm 8.0$ & & $81.1 \pm 6.4$ & $64.8 \pm 8.5$ & \\
\hline & 2 & $67(64.4 \%)$ & $65.7 \pm 5.8$ & $55.9 \pm 6.4$ & & $55.2 \pm 6.1$ & $46.9 \pm 6.5$ & \\
\hline
\end{tabular}

Significant results are shown in italics

and high-risk groups was calculated. In this collective, a DOI cut-off of $6 \mathrm{~mm}$ was ideal to separate these two groups (OS: $\chi^{2}(1)=7.601, p=0.006$; RFS: $\left.\chi^{2}(1)=8.912, p=0.003\right)$. In literature, most commonly a cut-off of $5 \mathrm{~mm}$ is described [24, $25]$. When applying this value in order to separate the groups, DOI was still a significant parameter estimating OS $\left(\chi^{2}(1)=\right.$ 
5.980, $p=0.014)$ and $\operatorname{RFS}\left(\chi^{2}(1)=7.860, p=0.005\right)$. Additionally, all cases were then divided up into subgroups of $\leq 5 \mathrm{~mm}, 5<\mathrm{DOI} \leq 10 \mathrm{~mm}$ and $>10 \mathrm{~mm}$ according to the current TNM classification [16, 21] (see Figs. 3 and 4). This categorical division of DOI was also a significant predictor of OS and RFS.

Resection margin (RM) on the other hand could not be identified as a significant predictor of OS or RFS. Patients were then summarized into subgroups $(\mathrm{RM} \leq 1 \mathrm{~mm}, 1 \mathrm{~mm}$ $<\mathrm{RM} \leq 5 \mathrm{~mm},>5 \mathrm{~mm}$ ) according to values previously published as significant prognostic indicators [26, 27], also yielding no significant result.

When restaging tumors according to the 8th edition of TNM classification of malignant tumors [15], using DOI as an additional parameter, new pT-stage was a significant predictor of OS and RFS, pointing towards a slight improvement in predictive power, when compared with the old classification (Figs. 3 and 4). Restaging led to an upstaging of pT1 to pT2 in $25.5 \%$ of the cases, pT1 to pT3 in $2.9 \%$, and pT2 to pT3 in $30.8 \%$. This new pT-stage and the information of extracapsular spread (ECS) obtained from the histopathological reports were then used to evaluate UICC (8th edition) [15] cancer stage for every case. There was an upstaging from stage I to stage II in $6.7 \%$ of the cases, from stage II to stage III in $4.4 \%$, from stage III to stage IVa in $0.7 \%$, from stage III to stage IVb also in $0.7 \%$, and from stage IVa to stage IVb in $10.4 \%$.

a

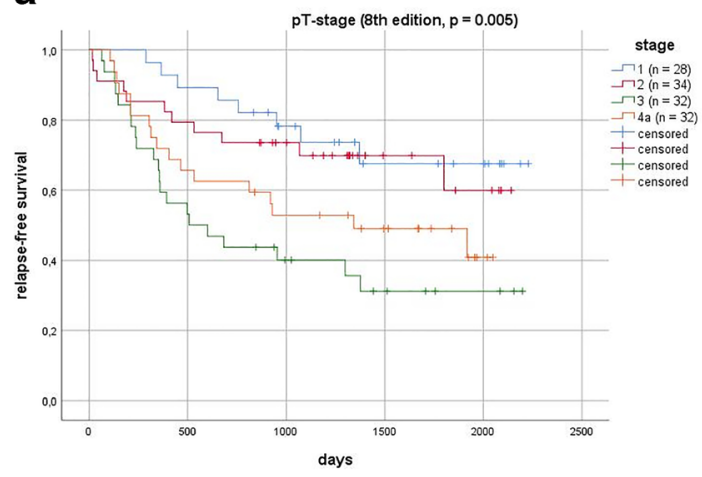

C

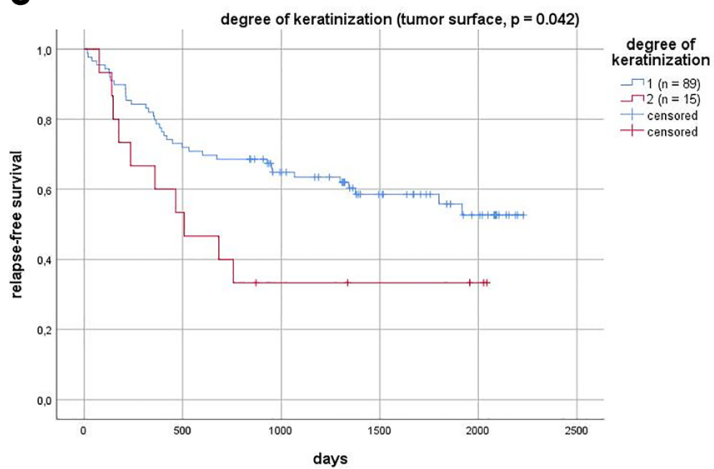

\section{Malignancy grading of tumor surface}

Degree of keratinization on a 4-point scale could not be identified as a significant predictor of OS or RFS. A binary scale was then applied by grouping together patients with highly $($ score $=1)$ or moderately $($ score $=2$ ) keratinized TS in one new subgroup (group 1) and patients with minimal $($ score $=3)$ or no $($ score $=4)$ keratinization at the TS into another subgroup (group 2). Difference in OS in both groups with a 2 YSR in group 1 of $78.7 \pm 4.3 \%$ and in group 2 of $53.3 \pm 12.9 \%$ and a 5YSR in group 1 of $65.7 \pm 5.8 \%$ and in group 2 of $38.9 \pm 12.9 \%$ was significant $\left(\chi^{2}(1)=4.752, p=0.029\right)$ (Fig. 3). RFS did also differ significantly after dichotomizing the results $\left(\chi^{2}(1)=4.144, p=0.042\right)$ (Fig. 4).

Pattern of growth on a four-point scale could not be identified as a significant predictor of OS or RFS. After dichotomizing this variable, there was a significant difference in OS $\left(\chi^{2}(1)=4.753, p=0.029\right)$ (Fig. 3) and RFS $\left(\chi^{2}(1)=4.582, p=0.032\right.$ ) (Fig. 4) between the new subgroups. 2YSR (OS) in new group 1 was $91.9 \pm 4.5 \%$ and $65.7 \pm 5.8 \%$ in group $2 ; 5$ YSR were $74.9 \pm 8.0 \%$ and 55.9 $\pm 6.4 \%$, respectively. Analyzing the single subgroups, there was a significant difference in OS of patients with grade 1 (pushing, well-delineated borders) and grade 2 (infiltrating, solid cords, bands and/or strands) tumors

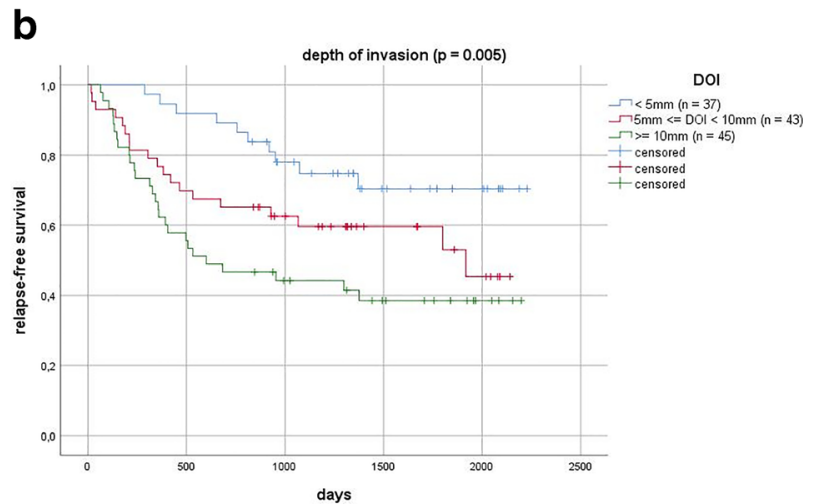

d

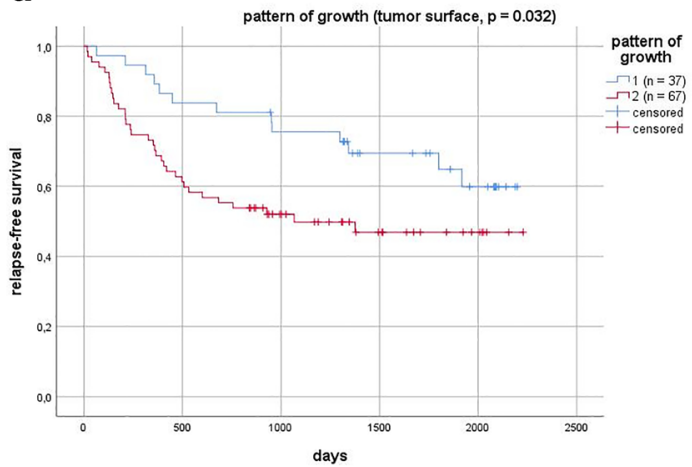

Fig. 3 Kaplan-Meier overall survival for pT-stage (A, $p=0.023)$, depth of invasion (B, $p=0.021)$, degree of keratinization $(\mathbf{C}, p=0.029)$, and pattern of growth $(\mathbf{D}, p=0.029)$ 
a

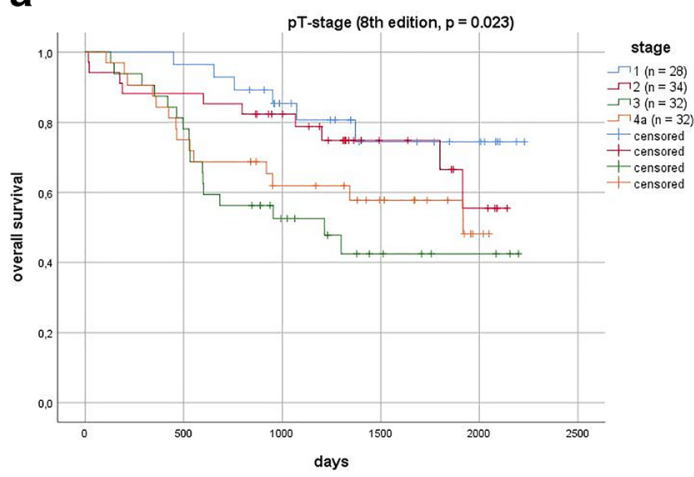

C

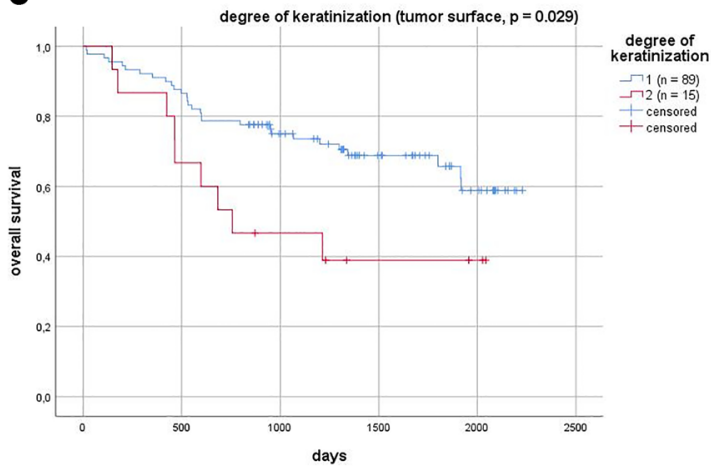

b

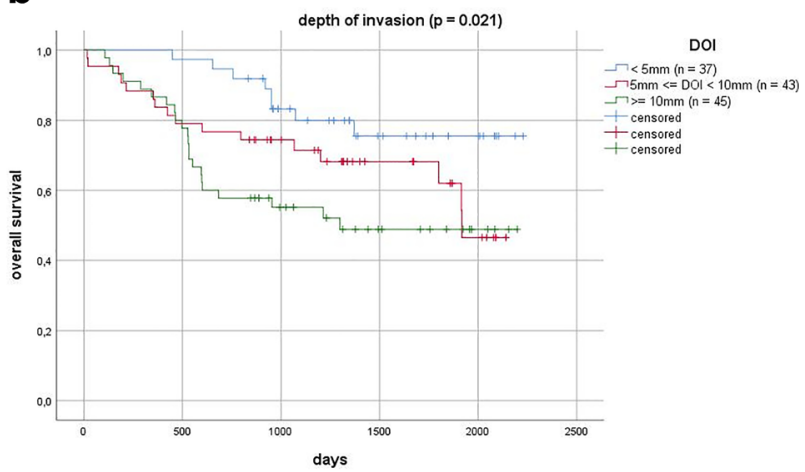

d

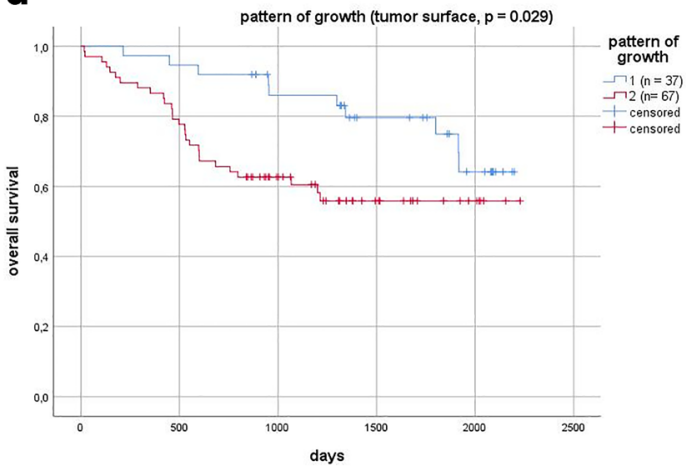

Fig. 4 Kaplan-Meier relapse-free survival for pT-stage $(\mathbf{A}, p=0.005)$, depth of invasion $(\mathbf{B}, p=0.005)$, degree of keratinization $(\mathbf{C}, p=0.042)$, and pattern of growth $(\mathbf{D}, p=0.032)$

when compared to grade 4 tumors (cellular dissociation) $\left(\chi^{2}(1)=4.436, p=0.035\right.$, and $\chi^{2}(1)=5.060, p=0.024$, respectively).

There was no difference in OS or RFS found when comparing patients grouped according to nuclear polymorphism, number of mitoses, or lymphoplasmacytic infiltration at the TS.

All measurements performed on the TS were then added up to create a combined malignancy score with a theoretical range of 5-20. Univariate analysis of this combined tumor surface malignancy score revealed it to be a significant predictor of $\operatorname{OS}(\operatorname{Exp}(B)=1.160, p=0.019)$ and RFS $(\operatorname{Exp}(B)=$ $1.160, p=0.019)$. A cut-off value of 13 was ideal to separate low-risk and high-risk groups concerning $\operatorname{OS}\left(\chi^{2}(1)=5.295\right.$, $p=0.021)$ and $\operatorname{RFS}\left(\chi^{2}(1)=15.886, p<0.000\right)$.

\section{Malignancy grading of invasion front}

There was no significant difference in OS or RFS when analyzing lymphoplasmacytic infiltration at the site of the IF. However, when looking at the most extreme subgroups with either a marked lymphoplasmacytic infiltration $($ score $=1)$ or no lymphoplasmacytic infiltration at all $($ score $=4)$, there was a significant difference in OS $\left(\chi^{2}(1)=3.973, p=0.046\right)$. Furthermore, a marked
$($ score $=1)$ and moderate $($ score $=2)$ lymphoplasmacytic infiltration was associated with a significantly higher RFS than in cases, where no lymphoplasmacytic infiltration $($ score $=4)$ was present $\left(\chi^{2}(1)=8.052, p=0.005\right.$, and $\chi^{2}(1)=4.192, p=0.041$, respectively).

There was no significant difference in OS or RFS, when comparing patients grouped according to degree of keratinization, nuclear polymorphism, number of mitoses, or pattern of invasion at the IF.

Also, the combined IF malignancy grading score was not a significant predictor of $\operatorname{OS}(\operatorname{Exp}(B)=1.097, p=0.131)$ or RFS $(\operatorname{Exp}(B)=1.093, p=0.112)$.

\section{Multivariate survival analysis}

All single parameters (new pT $1+2$ vs $3+4, \mathrm{~V}, \mathrm{Pn}, \mathrm{LM}$, degree of keratinization $1+2$ vs $3+4$, pattern of growth $1+2$ vs $3+4$, DOI with a cut-off of $5 \mathrm{~mm}$ ) that had shown significant impact on OS were then integrated into a multivariate Cox regression model. In this analysis, only V1 was identified as independent, significant factor associated with reduced OS (Table 4). When performing this analysis regarding RFS, no parameter could be identified as a significant factor. 
Table 4 Multivariate analysis (overall survival)

\begin{tabular}{lccc}
\hline Parameter & Number & $\operatorname{Exp}(\mathrm{B})$ & Test result \\
\hline Depth of invasion $\geq 5 \mathrm{~mm}$ & 81 & 2.815 & $p=0.108$ \\
Degree of keratinization 3+4 (surface) & 15 & 1.799 & $p=0.145$ \\
Pattern of growth 3+4 (surface) & 66 & 1.827 & $p=0.147$ \\
pT3 + 4 & 56 & 0.919 & $p=0.838$ \\
Lymponodular metastasis pos. & 40 & 1.684 & $p=0.136$ \\
V1 & 3 & 5.136 & $p=0.014$ \\
Pn1 & 14 & 1.962 & $p=0.105$ \\
\hline
\end{tabular}

Significant results are shown in italics

\section{Predictive value of standard and additional histologic parameters concerning the presence of lymphonodular metastases}

Of all standard and staging parameters, younger age $(T=$ $2.220, p=0.029)$, infiltration of lymphatic vessels $\left(\chi^{2}(1)=\right.$ $8.788, p=0.003, \phi=0.256$ ), and infiltration of nerves $\left(\chi^{2}(1)=6.597, p=0.010, \phi=0.222\right)$ were significantly correlated with LM. The ideal cut-off to discriminate low- and high-risk groups for LM regarding age was 60 years $\left(\chi^{2}(1)=\right.$ $6.610, p=0.010, \phi=0.222$ ). Rate of LM was $50.0 \%$ in patients younger than 60 years and $28.0 \%$ in patients with an age of 60 years or older.

Mean DOI in patients without LM was $7.71 \mathrm{~mm}$ compared to $9.73 \mathrm{~mm}$ in patients with the presence of LM. This difference was significant $(T=-2.163, \mathrm{df}=122, p=0.032)$. A cutoff value off $5 \mathrm{~mm}$ was found to be ideal to separate low-risk and high-risk groups $\left(\chi^{2}(1)=4.600, p=0.032, \phi=0.193\right)$. Rate of LM was $24.3 \%$ in the group with DOI $<5 \mathrm{~mm}$ and $44.8 \%$ in the group with DOI $\geq 5 \mathrm{~mm}$.

New pT-stage according to the 8th edition of UICC cancer staging manual was a significant parameter associated with $\operatorname{LM}\left(\chi^{2}(3)=10.634, p=0.014, \phi=0.292\right)$.

Degree of keratinization at the IF on a 4-point and a 2point scale was a significant predictor regarding the presence of lymphonodular metastatic spread $\left(\chi^{2}(3)=8.715\right.$, $p=0.033, \phi=0.267$, and $\chi^{2}(1)=4.802, p=0.028, \phi=$ $0.198)$. There were significantly more patients without LM in score-group $1(23.9 \%)$ and more patients with LM in score-group 4 (66.7\%).

The parameter nuclear polymorphism at the IF, after regrouping all cases according to a binary scale, was significantly associated with $\operatorname{LM}\left(\chi^{2}(1)=4.106, p=0.043, \phi=0.183\right)$. Rate of LM in group 1 was $30.7 \%$ and $48.9 \%$ in group 2.

All other investigated parameters were not significantly correlated with the presence of LM.

All categorial parameters that had been found to be significantly correlated with the presence of LM were then added to multivariate regression model (see Table 5). Here, the age
Table 5 Association with lymphonodular metastasis (multivariate)

\begin{tabular}{llll}
\hline Parameter & Number & $\operatorname{Exp}(\mathrm{B})$ & test result \\
\hline Age <60 years & 46 & 2.569 & $p=0.031$ \\
pT1 (indicator) & 28 & & $p=0.087$ \\
pT2 & 31 & 2.308 & $p=0.194$ \\
pT3 & 30 & 5.289 & $p=0.012$ \\
pT4 & 31 & 1.994 & $p=0.282$ \\
Pn1 & 14 & 0.987 & $p=0.986$ \\
L1 & 10 & 4.125 & $p=0.121$ \\
Degree of keratinization & 41 & 1.403 & $p=0.487$ \\
$\quad 3+4$ (invasive front) & & & \\
Nuclear polymorphism & 47 & 1.816 & $p=0.201$ \\
$\quad 3+4$ (invasive front) & & & \\
\hline
\end{tabular}

Significant results are shown in italics

group below 60 years and new pT-stage 3 could be identified as independent, significant predictors of LM.

\section{Discussion}

The interpretation of our results regarding the malignancy grading system revealed a heterogenous picture.

\section{Number of mitoses}

The number of mitoses at both sites (surface and invasion front) reviewed and analyzed as exact number and coded as a score was not a suitable value to predict or estimate any outcome parameter. This finding corresponds to previous observations $[17,23,28]$, though a high mitotic activity is seen as a surrogate marker for poorly differentiated tumors associated with poor prognosis [29].

\section{Nuclear polymorphism}

Quite the same applied for our results on nuclear polymorphism. We did not see any statistical association of this parameter with any of the evaluated survival parameters. However, after combining the two lower and higher grades, the high-grade $(3+4)$ group of nuclear polymorphism at the site of the invasive front showed significantly more lymphonodular metastases compared to the low-grade $(1+$ 2) group. This corresponds well to the biological model of loss of differentiation and metastasizing and was reported before [30]. However, the discrepancy in the present study's findings could partly be explained with nuclear polymorphism being the most unreliable or uncertain parameter, as explained in one interrater study, where it reached the poorest interobserver agreement [31]. 


\section{Lymphoplasmacytic infiltration}

Lymphoplasmacytic infiltration is seen as inflammatory response of the host against tumor growth [18,32], and recently, immune-modulation-based strategies have become of increasing interest in the therapy of OSCC [33-35]. In this collective, patients with no lymphoplasmacytic infiltrate present at the site of the invasive front had the lowest OS when compared to patients with a marked lymphoplasmacytic infiltrate and the lowest RFS when compared to patients with either a marked or moderate inflammatory infiltrate. These results could not be seen when grading the more superficial cell layers of the tumor, possibly giving another hint that lymphocytes invading the tumor mass do indeed represent the host's counter-tumor activity [36-39].

\section{Degree of keratinization}

Keratinization or the lack thereof is often regarded as representing the grade of tissue differentiation of a tumor $[20,40]$ and several studies described a high degree of keratinization being associated with a better prognosis $[39,41]$ and a tendency to lower keratinization in cases of tumor recurrence [39]. In the present study, patients with higher degrees of keratinization (scores 1 and 2 combined) at the tumor surface showed a higher OS and RFS than patients with only minimal or no keratinization (scores 3 and 4 combined). In contrast, when assessing keratin formation at the invasive front, there was no significant difference between the groups. Also, the presence of LM was significantly lower in patients with highly keratinized cell formations at the invasive front and significantly higher in patients with no keratin formation at this site. Similar findings have been reported by other groups [28, 31].

\section{Pattern of invasion}

Grading systems for malignant diseases are supposed to describe relevant morphological characteristics of the tumor but should also be easy to use and reproducible [12, 31]. Concerning OSCC, classical categories to describe the whole tumor's morphology had been "structure," "pattern," and "mode of invasion" and these categories were subsumed by Anneroth under a new category "mode of invasion" in order to easily describe tumor growth and tumor-host interaction [20]. In contrast to Bryne's modification of the malignancy grading [22], all categories were applied to both the tumor surface and the invasive front. Also, in contrast to former reports [18, 22], pattern of invasion (POI) in this study was not significantly correlated to any prognostic values. Pattern of growth (POG) at the site of the tumor surface however did reveal a higher OS in score-group 1 and a higher OS and RFS in score-group 2, when compared with patients with score $=4$. After modifying this variable and creating a binary scale, there was a significant difference in OS and RFS between the two groups.

\section{Staging parameters}

In order to predict prognosis and choose the necessary treatment options, not only histological grading but also preoperative and postoperative tumor stage is very important and needs to be considered. All parameters, which are currently applied during routine work-up as staging variables and are ultimately used to define possible postoperative treatment, were evaluated. Infiltration of blood vessels and perineural Infiltration were found to be significant predictors of OS, while UICC stage and T-stage according to the 7th edition of the TNM classification of malignant tumors [21] were found to be significant predictors of OS and RFS. Infiltration of lymphatic vessels, perineural invasion, and an age younger than 60 years were significantly associated with LM, the latter in univariate and multivariate analysis. The survival rates presented in the present study roughly correspond to those reported in literature [42-44]. However, pT3 stage in this collective was associated with the lowest OS and RFS with a lower 2YSR and 5YSR than pT4a stage. Like other authors, we interpret this fact as small tumors showing bone invasion and therefore formally qualifying for pT4a stage [45]. In contrast to pT3-tumors deeply infiltrating the soft tissues, these cases can be very accessible for sufficient surgical treatment with a safe and complete tumor resection. The importance of initial free resection margins has been reported elsewhere [46]. To increase selectivity and implement results of ongoing research, there have been some changes in the current, 8th edition of the respective TNM staging manuals, mainly with introduction of DOI as a stage defining parameter $[15,16,45]$. Using the values gathered during the reported investigations, all cases were restaged to get a "new pT-stage." There are some indications that this reclassification did indeed slightly improve selectivity and thereby predictive power of the pT classification, and only the newly staged groups were significant predictors of LM. Still, the irregularities regarding OS and RFS in late-stage cancer (T3 and T4) mentioned earlier persist.

\section{Resection margins}

To address these issues, also two staging parameters, DOI and RM, which can be assessed during pathohistological examination of HE-slides, were evaluated separately. In concordance with other publications $[43,47,48]$ resection margin could not be identified as a significant predictor of survival or $\mathrm{LM}$, even when summarizing patients into subgroups $(\mathrm{RM} \leq$ $1 \mathrm{~mm}, \leq 5 \mathrm{~mm},>5 \mathrm{~mm}$ ) according to values previously published as significant prognostic indicators [26, 27]. These findings can possibly be explained with complete (R0) tumor 
resection being achieved in all patients of this collective and because mean RM was $6.0 \mathrm{~mm}$ and the number of patients with involved ( $\mathrm{RM} \leq 1 \mathrm{~mm}$ ) margins was only 5 . On the other hand, relapse does occur in patients with diagnosed free margins, so additional risk factors have to be evaluated [43, 49]. As mentioned before, positive frozen section margins or free margins only achieved by revision surgery are risk factors for local tumor relapse [46].

\section{Depth of invasion}

DOI on the other hand was found to be an independent predictor of OS, RSF, and LM. These findings concur with results published elsewhere $[24,50]$. Very often, cut-off-values defining the at-risk-group of $4 \mathrm{~mm} \mathrm{[49,51-53]} \mathrm{or} 5 \mathrm{~mm}$ [24] are reported and have even been implemented into UICC and AJCC pT-stages $[15,16]$, but there are also hints of little difference between these two groups, lastly advising the use of $5 \mathrm{~mm}$ out of practical considerations [25]. In the present study, DOI as an absolute value was identified of being an independent risk factor with a cut-off value between low-risk and high-risk groups at $6 \mathrm{~mm}$. Similarly, DOI has also been investigated in preoperative cancer biopsies with promising results [51]. It should however be emphasized that the tissue specimens are required to fulfill certain quality standards in order to be evaluated properly $[49,51,54]$. Additionally, definitions of DOI may vary $[50,55]$ and there is a widespread uncertainty in clearly separating DOI from measuring tumor thickness [25]. The concept of calculating a "relative DOI" by relating measured DOI with site-specific characteristics like the thickness of submucosal tissue has been promoted [49] but needs further investigation. Because of its relevance regarding outcome and the presence of LM, preoperative and adjuvant choice of therapeutic options, especially elective neck dissection, should take DOI into consideration. Though, due to contradicting reports [56, 57], it remains unclear, how to identify patients, especially with early-stage cancer, that would benefit from elective neck dissection. Several methods of evaluating DOI during the pretherapeutic staging process have been evaluated. There was a good correlation reported between clinical examination, MRI findings, and pathohistological results in tumors with DOI $>5 \mathrm{~mm}$ [58]. There are also data suggesting that intraoral ultrasound could be superior to other diagnostic entities and also applicable to early-stage cancer [59, 60].

\section{Conclusions}

In conclusion, some specific parameters like the mitotic count alone seem not to be valid prognostic parameters, while the heterogenous picture revealed, when assessing lymphoplasmacytic infiltration or degree of keratinization, suggests that these features could be helpful in predicting tumor-specific prognosis. The exact mode and procedure though remain unclear and need further evaluation. Analyzing OSCC's patterns of growth gives valuable diagnostic and prognostic information, but a valid scoring and interpretation system has yet to be created. Recently, similar or derived concepts like tumor budding and cell nests have been evaluated for other entities $[61,62]$ and OSCC $[12$, $17,51,63]$ with promising results. Dichotomizing complex histological grading systems partly sacrifices diagnostic accuracy, but it can increase reproducibility and specificity of the diagnosis $[31,64,65]$. We think further efforts should be made to evaluate cellular tumor grading systems and their modifications, as there seems to be room left for improvement concerning validity and applicability. Combining all results of the respective site by summation into one malignancy score revealed only the tumor surface malignancy score to be a significant predictor of OS and RFS. However, all considerations formerly mentioned taken into account, we conclude that its predictive power is mainly derived from single items being of high diagnostic value and at least single components of this score need further modifications.

$\mathrm{RM}$ as a metric or grouping parameter could not be identified as a valid prognostic factor for any of the outcome parameters investigated. Consecutively, we advocate the necessity of obtaining initial free RM with sufficient safety margins, but in the same moment would like to emphasize the importance of evaluating additional risk factors in each patient in order to select best treatment options.

DOI on the other hand was found to be a significant predictor for OS, RFS, and LM in metric and grouped analysis, and its integrations into standard staging procedure seem to have improved diagnostic quality.

\section{Clinical relevance}

In conclusion, DOI evolved as the single most important parameter that can be obtained during histopathological examination of tissue slides. Consecutively, staging indeed seems to be more important than grading. However, applicability and prognostic relevance of grading parameters can be improved, e.g., by making them more reproducible using binary scales. Care must be taken to establish standardized procedures from the moment of taking the biopsy until processing the tissue and clear definitions of DOI must be followed in order to obtain valid results.

Funding Information Open Access funding provided by Projekt DEAL.

\section{Compliance with ethical standards}

Conflict of interest The authors declare that they have no conflict of interest. 
Ethical approval The study was approved by the University of Regensburg Ethics Committee (University of Regensburg, no. 18-1112101 ), and it was conducted in accordance with the ethical standards of the declaration of Helsinki.

Informed consent Based on a retrospective analysis, a fully anonymized set of clinical data and in agreement with the decision of the Ethics Committee, signing an informed consent, was not required.

Abbreviations 2-year survival rate, 2YSR; 5-year survival rate, 5YSR; $D O I$, depth of invasion; $E C S$, extracapsular spread; $H E$, hematoxylin and

eosin; HNSCC, head and neck squamous cell carcinoma; $H P F$, high power field; $I C G$, invasive cell grading; $I F$, invasion front; $L M$, lymphonodular metastasis; $O S$, overall survival; $O S C C$, oral squamous cell carcinoma; $P D-L 1$, programmed death ligand $1 ; P O G$, pattern of growth; $P O I$, pattern of invasion; $R M$, resection margin; $R F S$, relapsefree survival; $T S$, tumor surface

Open Access This article is licensed under a Creative Commons Attribution 4.0 International License, which permits use, sharing, adaptation, distribution and reproduction in any medium or format, as long as you give appropriate credit to the original author(s) and the source, provide a link to the Creative Commons licence, and indicate if changes were made. The images or other third party material in this article are included in the article's Creative Commons licence, unless indicated otherwise in a credit line to the material. If material is not included in the article's Creative Commons licence and your intended use is not permitted by statutory regulation or exceeds the permitted use, you will need to obtain permission directly from the copyright holder. To view a copy of this licence, visit http://creativecommons.org/licenses/by/4.0/.

\section{References}

1. Marur S, Forastiere AA (2016) Head and neck squamous cell carcinoma: update on epidemiology, diagnosis, and treatment. Mayo Clin Proc 91(3):386-396

2. Rivera C (2015) Essentials of oral cancer. Int J Clin Exp Pathol 8(9):11884-11894

3. Cheraghlou S, Schettino A, Zogg CK, Judson BL (2018) Changing prognosis of oral cancer: an analysis of survival and treatment between 1973 and 2014. Laryngoscope 128(12):2762-2769

4. Ribeiro IP, Barroso L, Marques F, Melo JB, Carreira IM (2016) Early detection and personalized treatment in oral cancer: the impact of omics approaches. Mol Cytogenet 9:85

5. Kerawala C, Roques T, Jeannon JP, Bisase B (2016) Oral cavity and lip cancer: United Kingdom National Multidisciplinary Guidelines. J Laryngol Otol 130(S2):S83-S89

6. Wolff KD, Follmann M, Nast A (2012) The diagnosis and treatment of oral cavity cancer. Dtsch Arztebl Int 109(48):829-835

7. Colevas AD, Yom SS, Pfister DG, Spencer S, Adelstein D, Adkins D, Brizel DM, Burtness B, Busse PM, Caudell JJ, Cmelak AJ, Eisele DW, Fenton M, Foote RL, Gilbert J, Gillison ML, Haddad RI, Hicks WL, Hitchcock YJ, Jimeno A, Leizman D, Maghami E, Mell LK, Mittal BB, Pinto HA, Ridge JA, Rocco J, Rodriguez CP, Shah JP, Weber RS, Witek M, Worden F, Zhen W, Burns JL, Darlow SD (2018) NCCN guidelines insights: Head and neck cancers, version 1.2018. J Natl Compr Cancer Netw 16(5):479-490
8. Vermorken JB, Mesia R, Rivera F, Remenar E, Kawecki A, Rottey S, Erfan J, Zabolotnyy D, Kienzer HR, Cupissol D, Peyrade F, Benasso M, Vynnychenko I, De Raucourt D, Bokemeyer C, Schueler A, Amellal N, Hitt R (2008) Platinum-based chemotherapy plus cetuximab in head and neck cancer. N Engl J Med 359(11): 1116-1127

9. Ferris RL, Blumenschein G Jr, Fayette J, Guigay J, Colevas AD, Licitra L, Harrington K, Kasper S, Vokes EE, Even C, Worden F, Saba NF, Iglesias Docampo LC, Haddad R, Rordorf T, Kiyota N, Tahara M, Monga M, Lynch M, Geese WJ, Kopit J, Shaw JW, Gillison ML (2016) Nivolumab for recurrent squamous-cell carcinoma of the head and neck. N Engl J Med 375(19):1856-1867

10. Burtness B, Harrington KJ, Greil R, Soulieres D, Tahara M, de Castro G Jr, Psyrri A, Baste N, Neupane P, Bratland A, Fuereder T, BGM H, Mesia R, Ngamphaiboon N, Rordorf T, Wan Ishak WZ, Hong RL, Gonzalez Mendoza R, Roy A, Zhang Y, Gumuscu B, Cheng JD, Jin F, Rischin D, Investigators K (2019) Pembrolizumab alone or with chemotherapy versus cetuximab with chemotherapy for recurrent or metastatic squamous cell carcinoma of the head and neck (KEYNOTE-048): a randomised, open-label, phase 3 study. Lancet 394(10212):1915-1928

11. Harrington KJ, Ferris RL, Blumenschein G Jr, Colevas AD, Fayette J, Licitra L, Kasper S, Even C, Vokes EE, Worden F, Saba NF, Kiyota N, Haddad R, Tahara M, Grunwald V, Shaw JW, Monga M, Lynch M, Taylor F, DeRosa M, Morrissey L, Cocks K, Gillison ML, Guigay J (2017) Nivolumab versus standard, single-agent therapy of investigator's choice in recurrent or metastatic squamous cell carcinoma of the head and neck (CheckMate 141): health-related quality-of-life results from a randomised, phase 3 trial. Lancet Oncol 18(8):1104-1115

12. Boxberg M, Bollwein C, Johrens K, Kuhn PH, Haller B, Steiger K, Wolff KD, Kolk A, Jesinghaus M, Weichert W (2019) Novel prognostic histopathological grading system in oral squamous cell carcinoma based on tumour budding and cell nest size shows high interobserver and intraobserver concordance. J Clin Pathol 72(4): 285-294

13. Muller S (2017) Update from the 4th edition of the World Health Organization of Head and neck tumours: tumours of the Oral cavity and Mobile tongue. Head Neck Pathol 11(1):33-40

14. El-Naggar AK, Chan JKC, Rubin Grandis J, Takata T, Slootweg PJ, International Agency for Research on Cancer (2017) WHO classification of head and neck tumours. World Health Organization classification of tumours, vol ninth, 4th edn. International Agency for Research on Cancer, Lyon

15. Brierley J, Gospodarowicz MK, Wittekind C (2017) TNM classification of malignant tumours, 8th edn. John Wiley \& Sons, Inc., Chichester; Hoboken

16. Amin MB, American Joint Committee on Cancer., American Cancer Society (2017) AJCC cancer staging manual. Eight edition / editor-in-chief, Mahul B. Amin, MD, FCAP ; editors, Stephen B. Edge, MD, FACS and 16 others ; Donna M. Gress, RHIT, CTR Technical editor ; Laura R. Meyer, CAPM - Managing editor. edn. American Joint Committee on Cancer, Springer, Chicago

17. Boxberg M, Jesinghaus M, Dorfner C, Mogler C, Drecoll E, Warth A, Steiger K, Bollwein C, Meyer P, Wolff KD, Kolk A, Weichert W (2017) Tumour budding activity and cell nest size determine patient outcome in oral squamous cell carcinoma: proposal for an adjusted grading system. Histopathology 70(7):1125-1137

18. Bryne M (1998) Is the invasive front of an oral carcinoma the most important area for prognostication? Oral Dis 4(2):70-77

19. Po Wing Yuen A, Lam KY, Lam LK, Ho CM, Wong A, Chow TL, Yuen WF, Wei WI (2002) Prognostic factors of clinically stage I and II oral tongue carcinoma - a comparative study of stage, thickness, shape, growth pattern, invasive front malignancy grading, Martinez-Gimeno score, and pathologic features. Head Neck 24(6):513-520 
20. Anneroth G, Batsakis J, Luna M (1987) Review of the literature and a recommended system of malignancy grading in oral squamous cell carcinomas. Scand J Dent Res 95(3):229-249

21. Sobin LH, Gospodarowicz MK, Wittekind C, International union against cancer (2010) TNM classification of malignant tumours, 7th edn. Wiley-Blackwell, Chichester; Hoboken

22. Bryne M, Koppang HS, Lilleng R, Stene T, Bang G, Dabelsteen E (1989) New malignancy grading is a better prognostic indicator than Broders' grading in oral squamous cell carcinomas. J Oral Pathol Med 18(8):432-437

23. Bryne M, Koppang HS, Lilleng R, Kjaerheim A (1992) Malignancy grading of the deep invasive margins of oral squamous cell carcinomas has high prognostic value. J Pathol 166(4):375381

24. Caldeira PC, Soto AML, de Aguiar MCF, Martins CC (2019) Tumor depth of invasion and prognosis of early-stage oral squamous cell carcinoma: a meta-analysis. Oral Dis

25. Liu B, Amaratunga R, Veness M, Wong E, Abdul-Razak M, Coleman H, Gebski V, Sundaresan P (2020) Tumor depth of invasion versus tumor thickness in guiding regional nodal treatment in early oral tongue squamous cell carcinoma. Oral Surg Oral Med Oral Pathol Oral Radiol 129(1):45-50

26. Buchakjian MR, Ginader T, Tasche KK, Pagedar NA, Smith BJ, Sperry SM (2018) Independent predictors of prognosis based on oral cavity squamous cell carcinoma surgical margins. Otolaryngol Head Neck Surg 159(4):675-682

27. Rogers SN, Brown JS, Woolgar JA, Lowe D, Magennis P, Shaw RJ, Sutton D, Errington D, Vaughan D (2009) Survival following primary surgery for oral cancer. Oral Oncol 45(3):201-211

28. Weijers M, Snow GB, Bezemer PD, van der Waal I (2009) Malignancy grading is no better than conventional histopathological grading in small squamous cell carcinoma of tongue and floor of mouth: retrospective study in 128 patients. J Oral Pathol Med 38(4):343-347

29. Rodrigues RM, Bernardo VG, Da Silva SD, Camisasca DR, Faria PAS, Dias FL, Pinto LFR, Albano RM, Bergmann A, Lourenco SQC (2020) How pathological criteria can impact prognosis of tongue and floor of the mouth squamous cell carcinoma. J Appl Oral Sci 28:e20190198

30. Khwaja T, Tayaar AS, Acharya S, Bhushan J, Muddapur MV (2018) Pattern of invasion as a factor in determining lymph node metastasis in oral squamous cell carcinoma. J Cancer Res Ther 14(2):382-387

31. Sawair FA, Irwin CR, Gordon DJ, Leonard AG, Stephenson M, Napier SS (2003) Invasive front grading: reliability and usefulness in the management of oral squamous cell carcinoma. J Oral Pathol Med 32(1):1-9

32. Lindenblatt Rde C, Martinez GL, Silva LE, Faria PS, Camisasca DR, Lourenco Sde Q (2012) Oral squamous cell carcinoma grading systems - analysis of the best survival predictor. J Oral Pathol Med 41(1):34-39

33. Ahmadi N, Gao K, Chia N, Kwon MS, Palme CE, Gupta R, Clark J (2019) Association of PD-L1 expression in oral squamous cell carcinoma with smoking, sex, and p53 expression. Oral Surg Oral Med Oral Pathol Oral Radiol 128(6):631-638

34. Takahashi H, Sakakura K, Arisaka Y, Tokue A, Kaira K, Tada H, Higuchi T, Okamoto A, Tsushima Y, Chikamatsu K (2019) Clinical and biological significance of PD-L1 expression within the tumor microenvironment of oral squamous cell carcinoma. Anticancer Res 39(6):3039-3046

35. Cai Y, Wang F, Liu Q, Li Z, Li D, Sun Z (2019) A novel humanized anti-PD-1 monoclonal antibody potentiates therapy in oral squamous cell carcinoma. Investig New Drugs 37(5):799-809

36. Fang J, Li X, Ma D, Liu X, Chen Y, Wang Y, Lui VWY, Xia J, Cheng B, Wang Z (2017) Prognostic significance of tumor infiltrating immune cells in oral squamous cell carcinoma. BMC Cancer 17(1):375

37. Nguyen N, Bellile E, Thomas D, McHugh J, Rozek L, Virani S, Peterson L, Carey TE, Walline H, Moyer J, Spector M, Perim D, Prince M, McLean S, Bradford CR, Taylor JM, Wolf GT, Head NSPI (2016) Tumor infiltrating lymphocytes and survival in patients with head and neck squamous cell carcinoma. Head Neck 38(7):1074-1084

38. Huang Z, Xie N, Liu H, Wan Y, Zhu Y, Zhang M, Tao Y, Zhou H, Liu X, Hou J, Wang C (2019) The prognostic role of tumourinfiltrating lymphocytes in oral squamous cell carcinoma: a metaanalysis. J Oral Pathol Med 48(9):788-798

39. Vedam VK, Boaz K, Natarajan S (2014) Prognostic efficacy of nuclear morphometry at invasive front of oral squamous cell carcinoma: an image analysis microscopic study. Anal Cell Pathol (Amst) 2014:247853

40. Miguelanez-Medran BC, Pozo-Kreilinger JJ, Cebrian-Carretero JL, Martinez-Garcia MA, Lopez-Sanchez AF (2019) Oral squamous cell carcinoma of tongue: histological risk assessment. A pilot study. Med Oral Patol Oral Cir Bucal 24(5):e603-e609

41. Wolfer S, Elstner S, Schultze-Mosgau S (2018) Degree of keratinization is an independent prognostic factor in Oral squamous cell carcinoma. J Oral Maxillofac Surg 76(2):444-454

42. Le Campion A, Ribeiro CMB, Luiz RR, da Silva Junior FF, Barros HCS, Dos Santos KCB, Ferreira SJ, Goncalves LS, Ferreira SMS (2017) Low survival rates of oral and oropharyngeal squamous cell carcinoma. Int J Dent 2017:5815493

43. Stathopoulos P, Smith WP (2017) Analysis of survival rates following primary surgery of 178 consecutive patients with oral cancer in a large district general hospital. J Maxillofac Oral Surg 16(2):158163

44. Liao CT, Kang CJ, Lee LY, Hsueh C, Lin CY, Fan KH, Wang HM, $\mathrm{Ng} \mathrm{SH}$, Lin CH, Tsao CK, Fang TJ, Huang SF, Chang KP, Chang YL, Yang LY, Yen TC (2016) Association between multidisciplinary team care approach and survival rates in patients with oral cavity squamous cell carcinoma. Head Neck 38(Suppl 1):E1544E1553

45. Neck C, Ebrahimi A, Gil Z, Amit M, Yen TC, Liao CT, Chaturvedi P, Agarwal JP, Kowalski LP, Kreppel M, Cernea CR, Brandao J, Bachar G, Bolzoni Villaret A, Fliss D, Fridman E, Robbins KT, Shah JP, Patel SG, Clark JR, International Consortium for Outcome Research in H (2014) Primary tumor staging for oral cancer and a proposed modification incorporating depth of invasion: an international multicenter retrospective study. JAMA Otolaryngol Head Neck Surg 140(12):1138-1148

46. Ettl T, El-Gindi A, Hautmann M, Gosau M, Weber F, Rohrmeier C, Gerken M, Muller S, Reichert T, Klingelhoffer C (2016) Positive frozen section margins predict local recurrence in $\mathrm{R} 0$-resected squamous cell carcinoma of the head and neck. Oral Oncol 55:17-23

47. Brandwein-Gensler M, Teixeira MS, Lewis CM, Lee B, Rolnitzky L, Hille JJ, Genden E, Urken ML, Wang BY (2005) Oral squamous cell carcinoma: histologic risk assessment, but not margin status, is strongly predictive of local disease-free and overall survival. Am J Surg Pathol 29(2):167-178

48. Hasmat S, Ebrahimi A, Gao K, Low TH, Palme C, Gupta R, Clark J (2019) Multifocal perineural invasion is a better prognosticator than depth of invasion in oral squamous cell carcinoma. Head Neck 41(11):3992-3999

49. Huang TY, Hsu LP, Wen YH, Huang TT, Chou YF, Lee CF, Yang MC, Chang YK, Chen PR (2010) Predictors of locoregional recurrence in early stage oral cavity cancer with free surgical margins. Oral Oncol 46(1):49-55

50. Fives C, Feeley L, O'Leary G, Sheahan P (2016) Importance of lymphovascular invasion and invasive front on survival in floor of mouth cancer. Head Neck 38(Suppl 1):E1528-E1534 
51. Almangush A, Leivo I, Siponen M, Sundquist E, Mroueh R, Makitie AA, Soini Y, Haglund C, Nieminen P, Salo T (2018) Evaluation of the budding and depth of invasion (BD) model in oral tongue cancer biopsies. Virchows Arch 472(2):231-236

52. Bulbul MG, Zenga J, Puram SV, Tarabichi O, Parikh AS, Varvares MA (2019) Understanding approaches to measurement and impact of depth of invasion of oral cavity cancers: a survey of American head and neck society membership. Oral Oncol 99:104461

53. Larson AR, Kemmer J, Formeister E, El-Sayed I, Ha P, George J, Ryan W, Chan E, Heaton C (2019) Beyond depth of invasion: adverse pathologic tumor features in early Oral tongue squamous cell carcinoma. Laryngoscope

54. Berdugo J, Thompson LDR, Purgina B, Sturgis CD, Tuluc M, Seethala R, Chiosea SI (2019) Measuring depth of invasion in early squamous cell carcinoma of the Oral tongue: positive deep margin, extratumoral perineural invasion, and other challenges. Head Neck Pathol 13(2):154-161

55. Maghami E, Koyfman SA, Weiss J (2018) Personalizing postoperative treatment of head and neck cancers. Am Soc Clin Oncol Educ Book 38:515-522

56. Faisal M, Abu Bakar M, Sarwar A, Adeel M, Batool F, Malik KI, Jamshed A, Hussain R (2018) Depth of invasion (DOI) as a predictor of cervical nodal metastasis and local recurrence in early stage squamous cell carcinoma of oral tongue (ESSCOT). PLoS One 13(8): 0202632

57. Mann J, Julie D, Mahase SS, D'Angelo D, Potters L, Wernicke AG, Parashar B (2019) Elective neck dissection, but not adjuvant radiation therapy, improves survival in stage I and II oral tongue Cancer with depth of invasion $>4 \mathrm{~mm}$. Cureus 11(12):e6288

58. Alsaffar HA, Goldstein DP, King EV, de Almeida JR, Brown DH, Gilbert RW, Gullane PJ, Espin-Garcia O, Xu W, Irish JC (2016) Correlation between clinical and MRI assessment of depth of invasion in oral tongue squamous cell carcinoma. J Otolaryngol Head Neck Surg 45(1):61
59. Tarabichi O, Bulbul MG, Kanumuri VV, Faquin WC, Juliano AF, Cunnane ME, Varvares MA (2019) Utility of intraoral ultrasound in managing oral tongue squamous cell carcinoma: systematic review. Laryngoscope 129(3):662-670

60. Iida Y, Kamijo T, Kusafuka K, Omae K, Nishiya Y, Hamaguchi N, Morita K, Onitsuka T (2018) Depth of invasion in superficial oral tongue carcinoma quantified using intraoral ultrasonography. Laryngoscope 128(12):2778-2782

61. Ozer SP, Barut SG, Ozer B, Catal O, Sit M (2019) The relationship between tumor budding and survival in colorectal carcinomas. Rev Assoc Med Bras (1992) 65(12):1442-1447

62. Wei L, Delin Z, Kefei Y, Hong W, Jiwei H, Yange Z (2020) A classification based on tumor budding and immune score for patients with hepatocellular carcinoma. Oncoimmunology 9(1): 1672495

63. Shimizu S, Miyazaki A, Sonoda T, Koike K, Ogi K, Kobayashi JI, Kaneko T, Igarashi T, Ueda M, Dehari H, Miyakawa A, Hasegawa T, Hiratsuka H (2018) Tumor budding is an independent prognostic marker in early stage oral squamous cell carcinoma: with special reference to the mode of invasion and worst pattern of invasion. PLoS One 13(4):e0195451

64. Steigen SE, Soland TM, Nginamau ES, Laurvik H, Costea DE, Johannessen AC, Jebsen P, Bjerkli IH, Uhlin-Hansen L, HadlerOlsen E (2020) Grading of oral squamous cell carcinomas - intra and interrater agreeability: simpler is better? J Oral Pathol Med

65. Kujan O, Oliver RJ, Khattab A, Roberts SA, Thakker N, Sloan P (2006) Evaluation of a new binary system of grading oral epithelial dysplasia for prediction of malignant transformation. Oral Oncol 42(10):987-993

Publisher's note Springer Nature remains neutral with regard to jurisdictional claims in published maps and institutional affiliations. 